\title{
Faktor-Faktor yang Berhubungan dengan Kejadian Stunting pada Anak Usia 24-59 Bulan di Wilayah Kerja Puskesmas Andalas Kecamatan Padang Timur Kota Padang Tahun 2018
}

\author{
Eko Setiawan ${ }^{1}$, Rizanda Machmud ${ }^{2}$, Masrul $^{3}$
}

\begin{abstract}
Abstrak
Stunting merupakan keadaan indeks tinggi badan menurut umur di bawah minus dua standar deviasi berdasarkan standar WHO.. Stunting merupakan manifestasi jangka panjang faktor konsumsi diet berkualitas rendah, penyakit infeksi berulang, dan lingkungan. Tujuan penelitian ini adalah mengetahui faktor-faktor yang berhubungan dengan kejadian stunting pada anak usia 24-59 bulan. Jenis penelitian ini adalah studi analitik observasional dengan desain cross-sectional. Sebanyak 74 sampel dipilih secara simple random sampling. Penelitian dilakukan dari Maret sampai April 2018. Pengumpulan data dilakukan dengan pengukuran tinggi badan, wawancara dan pengisian kuesioner. Analisis bivariat menggunakan uji Chi-square dan multivariat menggunakan uji regresi logistik ganda. Hasil penelitian menunjukkan bahwa proporsi stunting sebesar 26,9 persen dan normal sebesar 73,1 persen. Hasil uji Chisquare menunjukkan terdapat hubungan yang bermakna antara tingkat asupan energi, riwayat durasi penyakit infeksi, berat badan lahir, tingkat pendidikan ibu dan tingkat pendapatan keluarga dengan kejadian stunting. Tingkat pendidikan ibu memiliki hubungan paling dominan dengan kejadian stunting. Penelitian ini menyarankan pemerintah, instansi kesehatan, dan pihak terkait berkolaborasi menerapkan kebijakan untuk mengurangi risiko stunting. Masyarakat disarankan mendapatkan pendidikan yang berkualitas, memberikan asupan nutrien yang seimbang dan meningkatkan derajat kesehatan anak.
\end{abstract}

Kata kunci: faktor-faktor, stunting, balita

\section{Abstract}

Stunting was a state of height-for-age index below minus two standard deviation based on WHO standard. Stunting was a long-term manifestation of low-quality dietary factor, recurrent infectious diseases, and environment. The objective of this study was to know the factors related to the incidence of stunting among children aged 24-59 months. The type of this research was observational with cross-sectional design. A total of 74 samples were selected by simple random sampling. The study was conducted in March-April 2018. Data were colected by measuring height, interviewing, and filling out questionnaires. Bivariate analysis used Chi-square and multivariate analysis used multiple logistic regression. The results showed that stunting proportion was 26.9 percent and normal 73.1 percent. Chi-square test showed that there were significant relationships between energy intake level, history of infectious disease duration, birth weight, mother's education level and family income level with the incidence of stunting and mother's education level had the most dominant relationship. This research suggested governments, health agencies and stakeholders to collaborate to implement policies to reduce stunting risks. People were advised to get quality education, provided balanced nutrient intake and improve the health of children.

Keywords: factors, stunting, toddler

Affiliasi penulis:1. Prodi Kedokteran Fakultas Kedokteran Universitas Andalas Padang (FK Unand), 2. Bagian IImu Kesehatan Masyarakat FK Unand, 3. Bagian IImu Gizi FK Unand
Korespondensi: Eko Setiawan, Email: ekosetiawan.yanti@gmail.com Telp: 081364470070 


\section{PENDAHULUAN}

Prevalensi stunting di Indonesia menempati peringkat kelima terbesar di dunia. ${ }^{1}$ Data Riset kesehatan dasar (Riskesdas) tahun 2013 menunjukkan prevalensi stunting dalam lingkup nasional sebesar 37,2 persen, terdiri dari prevalensi pendek sebesar 18,0 persen dan sangat pendek sebesar 19,2 persen. Stunting dianggap sebagai masalah kesehatan masyarakat yang berat bila prevalensi stunting berada pada rentang 30-39 persen. $\mathrm{Hal}$ ini menunjukkan bahwa Indonesia sedang mengalami masalah kesehatan masyarakat yang berat dalam kasus balita stunting. ${ }^{2}$

Masalah kurang gizi dan stunting merupakan dua masalah yang saling berhubungan. Stunting pada anak merupakan dampak dari defisiensi nutrien selama seribu hari pertama kehidupan. Hal ini menimbulkan gangguan perkembangan fisik anak yang irreversible, sehingga menyebabkan penurunan kemampuan kognitif dan motorik serta penurunan performa kerja. Anak stunting memiliki rerata skor Intelligence Quotient (IQ) sebelas poin lebih rendah dibandingkan rerata skor IQ pada anak normal. Gangguan tumbuh kembang pada anak akibat kekurangan gizi bila tidak mendapatkan intervensi sejak dini akan berlanjut hingga dewasa. ${ }^{3,4}$

Stunting pada balita perlu mendapatkan perhatian khusus karena dapat menyebabkan terhambatnya pertumbuhan fisik, perkembangan mental dan status kesehatan pada anak. Studi terkini menunjukkan anak yang mengalami stunting berkaitan dengan prestasi di sekolah yang buruk, tingkat pendidikan yang rendah dan pendapatan yang rendah saat dewasa. Anak yang mengalami stunting memiliki kemungkinan lebih besar tumbuh menjadi individu dewasa yang tidak sehat dan miskin. Stunting pada anak juga berhubungan dengan peningkatan kerentanan anak terhadap penyakit, baik penyakit menular maupun Penyakit Tidak Menular (PTM) serta peningkatan risiko overweight dan obesitas. Keadaan overweight dan obesitas jangka panjang dapat meningkatkan risiko penyakit degeneratif. Kasus stunting pada anak dapat dijadikan prediktor rendahnya kualitas sumber daya manusia suatu negara. Keadaan stunting menyebabkan buruknya kemampuan kognitif, rendahnya produktivitas, serta meningkatnya risiko penyakit mengakibatkan kerugian jangka panjang bagi ekonomi Indonesia. ${ }^{4,5}$

Pusat Kesehatan Masyarakat (Puskesmas) Andalas merupakan satu-satunya Puskesmas yang berada di Kecamatan Padang Timur. Wilayah kerja Puskesmas Andalas masih menghadapi berbagai masalah terkait kesehatan anak. Menurut Profil Kesehatan Kota Padang tahun 2016, jumlah kasus Bayi Berat Lahir Rendah (BBLR) dan gizi buruk pada balita di Kota Padang tahun 2016 paling tinggi terdapat di wilayah kerja Puskesmas Andalas. Selama tahun 2016, dilaporkan sebanyak 44 kasus BBLR dan 18 kasus gizi buruk. Kasus diare dan pneumonia pada balita juga tinggi di wilayah kerja Puskesmas Andalas. Dilaporkan sebanyak 649 kasus diare dan 386 kasus pneumonia pada balita selama tahun 2016. Jumlah tersebut menempati peringkat paling tinggi ketiga jumlah kasus diare dan pneumonia pada balita di Kota Padang pada tahun 2016. Persentase bayi yang diberi ASI eksklusif pada tahun 2016 juga rendah di Kecamatan Padang Timur, yaitu sebesar 57,12 persen. Persentase tersebut menempatkan Kecamatan Padang Timur sebagai kecamatan paling rendah dalam persentase anak yang mendapatkan ASI eksklusif se-Kota Padang. ${ }^{6}$

Penelitian ini bertujuan untuk mengetahui faktor-faktor yang berhubungan dengan kejadian stunting pada anak usia 24-59 bulan di wilayah kerja Puskesmas Andalas Kecamatan Padang Timur Kota Padang tahun 2018.

\section{METODE}

Penelitian ini merupakan studi analitik observasional dengan desain cross-sectional. Penelitian dilakukan di wilayah kerja Puskesmas Andalas Kecamatan Padang Timur Kota Padang dari bulan Agustus 2017 hingga bulan April 2018. Sebanyak 74 sampel dipilih secara simple random sampling dari seluruh anak usia 24-59 bulan dengan memperhatikan kriteria inklusi dan eksklusi

Data diperoleh dengan melakukan pengukuran TB terhadap anak dengan menggunakan microtoise, wawancara dan pengisisan kuesioner terhadap ibu. Hasil pengukuran TB selanjutnya diolah untuk mendapatkan status gizi anak dengan menggunakan standar WHO-2005, yaitu Z-skor indeks 
TB/U. Data mengenai tingkat asupan nutrien (energi dan protein) diperoleh dengan pengisian Food Frequency Questionnaire (FFQ) semi kuantitatif, kemudian diolah dengan Nutri Survey 2007. Data mengenai riwayat penyakit infeksi (durasi dan frekuensi), berat badan lahir, status pemberian ASI eksklusif, status kelengkapan imunisasi dasar, tingkat pendidikan ibu, tingkat pengetahuan ibu tentang gizi, tingkat pendapatan keluarga, dan jumlah anggota rumah tangga diperoleh dengan wawancara dan pengisian kuesioner.

Data dianalisis dengan analisis univariat untuk memperoleh gambaran distribusi frekuensi, analisis bivariat menggunakan uji Chi-square untuk memperleh hubungan dua variabel. Analisis multivariat menggunakan uji regresi logistik ganda untuk mengetahui variabel independen yang memiliki hubungan paling dominan dengan variabel dependen.

\section{HASIL}

Karakteristik keluarga terdiri dari: tingkat pendidikan ibu, tingkat pengetahuan ibu tentang gizi, tingkat pendapatan keluarga, dan jumlah anggota rumah tangga. Karakteristik keluarga ditampilkan dalam tabel distribusi frekuensi berikut.

Tabel 1. Distribusi frekuensi tingkat pendidikan ibu, tingkat pengetahuan ibu tentang gizi, tingkat pendapatan keluarga dan anggota rumah tangga

\begin{tabular}{|c|c|c|}
\hline Variabel & $f$ & $\%$ \\
\hline \multicolumn{3}{|l|}{ Tingkat Pendidikan Ibu } \\
\hline Pendidikan Rendah & 48 & 71,6 \\
\hline Pendidikan Tinggi & 19 & 28,4 \\
\hline \multicolumn{3}{|l|}{ Tingkat Pengetahuan Ibu tentang Gizi } \\
\hline Pengetahuan Kurang Baik & 6 & 9,0 \\
\hline Pengetahuan Baik & 61 & 91,0 \\
\hline \multicolumn{3}{|l|}{ Tingkat Pendapatan Keluarga } \\
\hline Miskin ( $\leq$ GK Kota Padang, Rp482.763,-) & 10 & 14,9 \\
\hline $\begin{array}{l}\text { Tidak Miskin (> GK Kota Padang, } \\
\text { Rp482.763,-) }\end{array}$ & 57 & 85,1 \\
\hline \multicolumn{3}{|l|}{ Jumlah Anggota Rumah Tangga } \\
\hline Keluarga Besar (ART > 4 orang) & 22 & 32,9 \\
\hline Keluarga Kecil (ART $\leq 4$ orang) & 45 & 67,1 \\
\hline
\end{tabular}

Lebih dari separuh (71,6 persen) ibu memiliki tingkat pendidikan rendah. Umumnya ( 91,0 persen) ibu memiliki pengetahuan yang baik tentang gizi.
Sebagian besar (85,1 persen) keluarga berada pada tingkat pendapatan di atas garis kemiskinan Kota Padang. Mayoritas (67,1 persen) keluarga tergolong keluarga kecil.

Karakteristik anak terdiri dari: usia, jenis kelamin, riwayat penyakit infeksi (durasi dan frekuensi), berat badan lahir, status pemberian ASI eksklusif, dan status kelengkapan imunisasi dasar. Karakteristik anak ditampilkan dalam tabel distribusi frekuensi berikut.

Tabel 2. Distribusi frekuensi usia, jenis kelamin, riwayat penyakit infeksi, berat badan lahir, status pemberian ASI eksklusif, dan status kelengkapan imunisasi dasar

\begin{tabular}{|c|c|c|}
\hline Variabel & $f$ & $\%$ \\
\hline \multicolumn{3}{|l|}{ Usia } \\
\hline 24-35 Bulan & 24 & 35,8 \\
\hline 36-47 Bulan & 23 & 34,3 \\
\hline 48-59 Bulan & 20 & 29,9 \\
\hline \multicolumn{3}{|l|}{ Jenis Kelamin } \\
\hline Laki-laki & 35 & 52,2 \\
\hline Perempuan & 32 & 47,8 \\
\hline \multicolumn{3}{|l|}{ Riwayat Penyakit Infeksi } \\
\hline \multicolumn{3}{|c|}{ Rerata Durasi Sakit (ISPA atau Diare) } \\
\hline$>3$ Hari per Episode Sakit & 23 & 34,3 \\
\hline$\leq 3$ Hari per Episode Sakit & 44 & 65,7 \\
\hline \multicolumn{3}{|c|}{ Rerata Frekuensi Sakit (ISPA dan Diare) } \\
\hline$>6$ Episode Sakit per Tahun & 8 & 11,9 \\
\hline$\leq 6$ Episode Sakit per Tahun & 59 & 88,1 \\
\hline \multicolumn{3}{|l|}{ Berat Badan Lahir } \\
\hline BBLR (BBL < 2.500 gram) & 5 & 7,5 \\
\hline Normal (BBL $\geq 2.500$ gram) & 62 & 92,5 \\
\hline \multicolumn{3}{|l|}{ Status Pemberian ASI Eksklusif } \\
\hline Bukan ASI Eksklusif & 25 & 37,3 \\
\hline ASI Eksklusif & 42 & 62,7 \\
\hline \multicolumn{3}{|c|}{ Status Kelengkapan Imunisasi Dasar } \\
\hline Tidak Lengkap & 15 & 22,4 \\
\hline Lengkap & 52 & 77,6 \\
\hline
\end{tabular}

Kelompok usia anak hampir merata. Kelompok usia 24-35 bulan memiliki frekuensi yang paling banyak (35,8 persen). Frekuensi jenis kelamin laki-laki sedikit lebih tinggi (52,2 persen) dibandingkan jenis kelamin perempuan. Lebih dari separuh anak memiliki riwayat durasi sakit $\leq 3$ hari per episode sakit, riwayat frekuensi sakit $\leq 6$ episode sakit per tahun, BBL normal, ASI eksklusif dan imunisasi lengkap. 
Karakteristik gizi terdiri dari: indeks TB/ $U$, tingkat asupan energi, dan tingkat asupan protein. Karakteristik gizi ditampilkan dalam diagram distribusi frekuensi berikut.

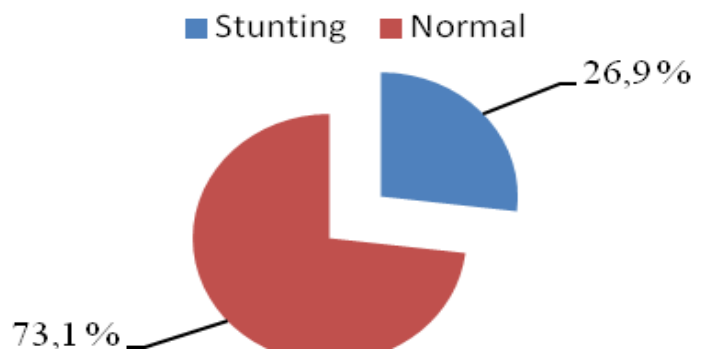

Gambar 1. Distribusi frekuensi indeks TB/U

Gambar 1 menunjukkan bahwa sebagian besar (73,1 persen) anak memiliki indeks TB/U normal.

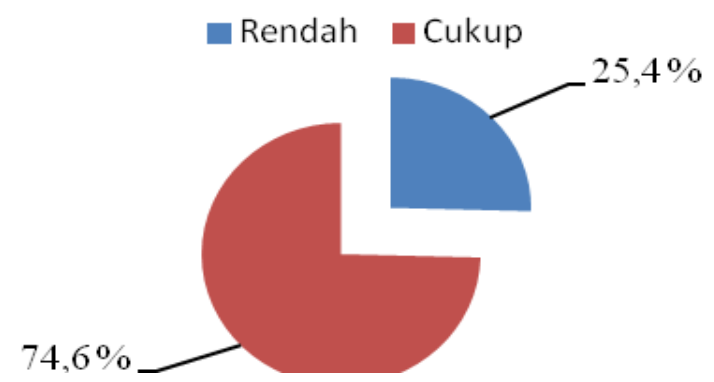

Gambar 2. Distribusi frekuensi tingkat asupan energi
Berdasarkan Gambar 2, dapat dilihat bahwa sebagian besar (74,6 persen) anak memiliki tingkat asupan energi cukup.

$82,1 \%$

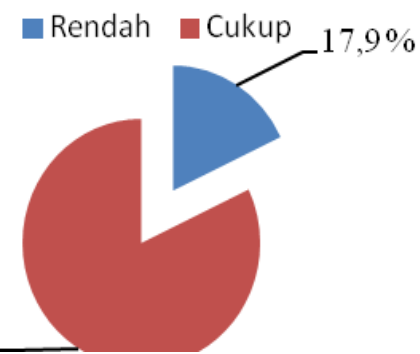

Gambar 3. Distribusi frekuensi tingkat asupan protein

Berdasarkan Gambar 3, terlihat bahwa umumnya (82,1 persen) anak berada pada tingkat asupan protein cukup.

Hasil analisis bivariat ditampilkan dalam tabel berikut. 
Tabel 3. Hubungan antara tingkat asupan energi, tingkat asupan protein, riwayat penyakit infeksi, berat badan lahir, status pemberian ASI eksklusif, status kelengkapan imunisasi dasar, tingkat pendidikan ibu, tingkat pengetahuan ibu tentang gizi, tingkat pendapatan keluarga, dan jumlah anggota rumah tangga dengan indeks TB/U

\begin{tabular}{|c|c|c|c|c|c|c|}
\hline \multirow[t]{2}{*}{ Variabel } & \multicolumn{2}{|c|}{ Stunting } & \multicolumn{2}{|c|}{ Normal } & OR & \multirow[b]{2}{*}{$\mathbf{P}$} \\
\hline & $\mathbf{f}$ & $\%$ & f & $\%$ & $(95 \% \mathrm{Cl})$ & \\
\hline \multicolumn{7}{|l|}{ Tingkat Asupan Energi } \\
\hline Rendah (< 100 persen AKG) & 10 & 58,8 & 7 & 41,2 & 7,5 & 0,001 \\
\hline Cukup ( $\geq 100$ persen $A K G)$ & 8 & 16,0 & 42 & 84,0 & $(2,2-25,6)$ & \\
\hline \multicolumn{7}{|l|}{ Tingkat Asupan Protein } \\
\hline Rendah (< 100 persen AKG) & 5 & 41,7 & 7 & 58,3 & 2,3 & 0,281 \\
\hline Cukup ( $\geq 100$ persen AKG) & 13 & 23,6 & 42 & 76,4 & $(0,6-8,5)$ & \\
\hline \multicolumn{7}{|l|}{ Riwayat Penyakit Infeksi } \\
\hline \multicolumn{7}{|l|}{ Rerata Durasi Sakit (ISPA atau Diare) } \\
\hline$>3$ Hari per Episode Sakit & 12 & 52,2 & 11 & 47,8 & 6,9 & 0,001 \\
\hline$\leq 3$ Hari per Episode Sakit & 6 & 13,6 & 38 & 86,4 & $(2,1-22,7)$ & \\
\hline \multicolumn{7}{|c|}{ Rerata Frekuensi Sakit (ISPA dan Diare) } \\
\hline$>6$ Episode Sakit per Tahun & 3 & 37,5 & 5 & 62,5 & 1,8 & 0,672 \\
\hline$\leq 6$ Episode Sakit per Tahun & 15 & 25,4 & 44 & 74,6 & $(0,4-8,3)$ & \\
\hline \multicolumn{7}{|l|}{ Berat Badan Lahir } \\
\hline BBLR (BBL <2.500 gram) & 4 & 80,0 & 1 & 20,0 & 13,7 & 0,016 \\
\hline Normal (BBL $\geq 2.500$ gram) & 14 & 22,6 & 48 & 77,4 & $(1,4-132,8)$ & \\
\hline \multicolumn{7}{|l|}{ Status Pemberian ASI Eksklusif } \\
\hline Bukan ASI Eksklusif & 8 & 32,0 & 17 & 68,0 & 1,5 & 0,464 \\
\hline ASI Eksklusif & 10 & 23,8 & 32 & 76,2 & $(0,5-4,5)$ & \\
\hline \multicolumn{7}{|l|}{ Status Kelengkapan Imunisasi Dasar } \\
\hline Tidak Lengkap & 4 & 26,7 & 11 & 73,3 & 1,0 & 1,000 \\
\hline Lengkap & 14 & 26,9 & 38 & 73,1 & $(0,3-3,6)$ & \\
\hline \multicolumn{7}{|l|}{ Tingkat Pendidikan Ibu } \\
\hline Pendidikan Rendah & 17 & 35,4 & 31 & 64,6 & 9,9 & 0,012 \\
\hline Pendidikan Tinggi & 1 & 5,3 & 18 & 94,7 & $(1,2-80,5)$ & \\
\hline \multicolumn{7}{|l|}{ Tingkat Pengetahuan Ibu tentang Gizi } \\
\hline Pengetahuan Kurang Baik & 3 & 50,0 & 3 & 50,0 & 3,1 & 0,331 \\
\hline Pengetahuan Baik & 15 & 24,6 & 46 & 75,4 & $(0,6-16,8)$ & \\
\hline \multicolumn{7}{|l|}{ Tingkat Pendapatan Keluarga } \\
\hline Miskin ( $\leq$ GK Kota Padang) & 6 & 60,0 & 4 & 40,0 & 5,6 & 0,018 \\
\hline Tidak Miskin > GK Kota Padang & 12 & 21,1 & 45 & 78,9 & $(1,4-23,2)$ & \\
\hline \multicolumn{7}{|l|}{ Jumlah Anggota Rumah Tangga } \\
\hline Keluarga Besar $(\mathrm{ART}>4)$ & 5 & 22,7 & 17 & 77,3 & 0,7 & 0,593 \\
\hline Keluarga Kecil $(\mathrm{ART} \leq 4)$ & 13 & 28,9 & 32 & 71,1 & $(0,2-2,4)$ & \\
\hline
\end{tabular}

Tabel 3 menunjukkan bahwa terdapat hubungan yang bermakna antara tingkat asupan energi, rerata durasi sakit, berat badan lahir, tingkat pendidikan ibu, dan tingkat pendapatan keluarga dengan kejadian stunting pada anak usia 24-59 bulan di wilayah kerja Puskesmas Andalas Kecamatan Padang Timur Kota Padang. Tingkat asupan protein, rerata frekuensi sakit, status pemberian ASI eksklusif, status kelengkapan imunisasi dasar, tingkat pengetahuan ibu tentang gizi, dan jumlah anggota rumah tangga tidak menunjukkan hubungan yang signifikan dengan kejadian stunting pada anak usia 24-59 bulan di wilayah kerja Puskesmas Andalas Kecamatan Padang Timur Kota Padang. Variabel independen terpilih adalah variabel independen yang memiliki $p<0,25$. 
Tabel 4. Seleksi kandidat analisis multivariat berdasarkan hasil analisis bivariat

\begin{tabular}{llc}
\hline No. & \multicolumn{1}{c}{ Variabel } & p \\
\hline 1 & Tingkat Asupan Energi & 0,001 \\
2 & Tingkat Asupan Protein & 0,281 \\
3 & Riwayat Durasi Penyakit Infeksi & 0,001 \\
4 & Riwayat Frekuensi Penyakit Infeksi & 0,672 \\
5 & Berat Badan Lahir & 0,016 \\
6 & Status Pemberian ASI Eksklusif & 0,464 \\
7 & Status Kelengkapan Imunisasi Dasar & 1,000 \\
8 & Tingkat Pendidikan Ibu & 0,012 \\
9 & Tingkat Pengetahuan Ibu tentang Gizi & 0,331 \\
10 & Tingkat Pendapatan Keluarga & 0,018 \\
\hline
\end{tabular}

Terdapat lima variabel independen yang memiliki $p<0,25$, yaitu: tingkat asupan energi, riwayat durasi penyakit infeksi, berat badan lahir, tingkat pendidikan ibu, dan tingkat pendapatan keluarga. Lima variabel tersebut dimasukkan ke dalam pemodelan analisis multivariat. Dilakukan pengeluaran variabel yang memiliki $\mathrm{p}$ value $>0,05$, dimulai dari variabel dengan $\mathrm{p}$ value yang paling besar secara bertahap (metode backward selection). Pemodelan analisis multivariat ditampilkan dalam tabel berikut.

Tabel 5. Pemodelan analisis multivariat

\begin{tabular}{llrrrrrr}
\hline \multirow{2}{*}{ No. } & & \multicolumn{2}{c}{ Model I } & \multicolumn{2}{c}{ Model II } & \multicolumn{2}{c}{ Model III } \\
\cline { 3 - 8 } & & $\mathbf{p}$ & OR & $\mathbf{p}$ & OR & P & OR \\
\hline 1 & Tingkat Asupan Energi & 0,012 & 7,4 & 0,009 & 7,4 & 0,006 & 7,8 \\
2 & Riwayat Durasi Penyakit Infeksi & 0,017 & 6,0 & 0,007 & 7,2 & 0,005 & 7,7 \\
3 & Berat Badan Lahir & 0,200 & 15,1 & - & - & - & - \\
4 & Tingkat Pendidikan Ibu & 0,082 & 8,0 & 0,081 & 8,0 & 0,048 & 10,5 \\
5 & Tingkat Pendapatan Keluarga & 0,137 & 4,0 & 0,146 & 3,8 & - & - \\
\hline
\end{tabular}

Berdasarkan Model I analisis multivariat, variabel berat badan lahir merupakan variabel dengan nilai $p$ paling besar, sehingga dikeluarkan dari pemodelan. Model II menunjukkan bahwa variabel tingkat pendapatan keluarga merupakan variabel yang memiliki nilai $p$ yang paling besar, sehingga dikeluarkan dari pemodelan. Terdapat tiga variabel yang masuk model III, yaitu: tingkat asupan energi, riwayat durasi penyakit infeksi, dan tingkat pendidikan ibu. Model III menunjukkan bahwa bahwa variabel tingkat pendidikan ibu memiliki $p<0,05$ dan nilai OR paling besar. Dapat disimpulkan bahwa variabel tingkat pendidikan ibu merupakan variabel yang memiliki hubungan paling dominan dengan kejadian stunting pada anak usia 2459 bulan di wilayah kerja Puskesmas Andalas Kecamatan Padang Timur Kota Padang tahun 2018.

\section{PEMBAHASAN}

\section{Gambaran Kejadian Stunting}

Persentase kejadian stunting pada penelitian sebesar 26,9 persen. Persentase tersebut lebih rendah dibandingkan prevalensi kejadian stunting nasional berdasarkan data Riskesdas 2013 yaitu sebesar 37,2 persen, tetapi lebih tinggi dibandingkan persentase stunting secara global menurut UNICEF, yaitu 22,9 persen. ${ }^{1,2}$

\section{Hubungan Karakteristik Keluarga dengan Kejadian Stunting}

Ada hubungan yang bermakna antara tingkat pendidikan ibu dengan kejadian stunting. Hasil yang sama diperoleh penelitian yang dilakukan di wilayah Puskesmas Cempaka, Banjarbaru, Kalimantan Selatan. Penelitian tersebut menyimpulkan bahwa terdapat hubungan yang bermakna antara tingkat pendidikan ibu dengan kejadian stunting pada anak. ${ }^{7}$ Berdasarkan analisis multivariat, faktor pendidikan ibu merupakan faktor yang memiliki hubungan paling dominan dengan kejadian stunting pada anak. Tingkat pendidikan memiliki pengaruh terhadap kesehatan, salah satunya adalah status gizi. Individu yang memiliki tingkat pendidikan tinggi memiliki kemungkinan lebih besar mengetahui pola hidup sehat dan cara menjaga tubuh tetap bugar yang tercermin dari penerapan pola hidup sehat seperti konsumsi diet bergizi. Individu dengan tingkat pendidikan tinggi cenderung menghindari 
kebiasaan buruk seperti rokok dan alkohol, sehingga memiliki status kesehatan yang lebih baik. Tingkat pendidikan juga berhubungan dengan pendapatan, dimana tingkat pendapatan cenderung meningkat seiring peningkatan tingkat pendidikan. Pendapatan yang cukup memungkinkan untuk hidup dengan kualitas yang lebih baik. Tingkat pendidikan juga mempengaruhi tingkat pengetahuan. Tingkat pengetahuan yang baik membantu pemilihan makanan dengan bijak dan tepat, serta penanganan gangguan kesehatan dengan baik. ${ }^{8}$

Tidak terdapat hubungan yang signifikan antara tingkat pengetahuan ibu tentang gizi dengan kejadian stunting. Penelitian yang dilakukan di Desa Mopusi, Kecamatan Lolayan, Kabupaten Bolaang Mongondow Induk, Provinsi Sulawesi Utara juga mendapatkan hasil yang sama, yaitu tidak ada hubungan yang signifikan antara tingkat pengetahuan ibu tentang gizi dengan kejadian stunting pada anak usia 1-3 tahun. ${ }^{9}$ Hal ini disebabkan oleh tumbuh kembang anak dipengaruhi oleh faktor-faktor keluarga lainnya, seperti: pekerjaan/ pendapatan keluarga, pendidikan orang tua, stabilitas rumah tangga, dan kepribadian orang tua. ${ }^{10}$

Tingkat pendapatan keluarga memiliki hubungan yang bermakna dengan kejadian stunting. Penelitian ini sejalan dengan penelitian yang dilakukan di Kota Banda Aceh, dimana tingkat pendapatan keluarga merupakan salah satu faktor yang memiliki hubungan bermakna dengan kejadian stunting pada balita. ${ }^{11}$ Status ekonomi rendah dianggap memiliki pengaruh yang dominan terhadap kejadian kurus dan pendek pada anak. Orang tua dengan pendapatan keluarga yang memadai akan memiliki kemampuan untuk menyediakan semua kebutuhan primer dan sekunder anak. Keluarga dengan status ekonomi yang baik juga memiliki akses pelayanan kesehatan yang lebih baik. ${ }^{12}$ Anak pada keluarga dengan status ekonomi rendah cenderung mengkonsumsi makanan dalam segi kuantitas, kualitas, serta variasi yang kurang. Status ekonomi yang tinggi membuat seseorang memilih dan membeli makanan yang bergizi dan bervariasi. ${ }^{13}$

Analisis data menyimpulkan bahwa antara jumlah anggota rumah tangga dengan kejadian stunting tidak memiliki hubungan yang signifikan. Penelitian yang dilakukan di wilayah kerja Puskesmas Kedungbanteng Banyumas juga menemukan bahwa jumlah anggota keluarga tidak memilki hubungan yang signifikan dengan kejadian stunting pada anak batita. ${ }^{14}$ Hal ini disebabkan status gizi memiliki banyak faktor, tidak hanya dipengaruhi oleh jumlah anggota rumah tangga. Status gizi juga dipengaruhi oleh dukungan keluarga dalam pemberian makanan bergizi dan status sosial ekonomi keluarga. ${ }^{12}$ Jumlah anggota rumah tangga tidak menjamin secara mutlak status gizi anggotanya. Jumlah anggota rumah tangga yang banyak apabila diimbangi dengan asupan nutrien yang cukup akan menurunkan risiko stunting. ${ }^{15}$

\section{Hubungan Karakteristik Keluarga dengan Kejadian Stunting}

Hubungan yang bermakna antara rerata durasi penyakit infeksi (ISPA atau diare) dengan kejadian stunting. Hasil penelitian ini sesuai dengan penelitian yang dilakukan di Desa Kopandakan Kecamatan Kotamobagu Selatan yang mendapatkan bahwa rerata durasi sakit saat balita $>3$ hari per episode sakit memiliki hubungan yang bermakna dengan kejadian stunting pada anak SD. ${ }^{16}$ Penelitian di Malawi menemukan bahwa peningkatan durasi diare dan ISPA berhubungan dengan penurunan status gizi anak. Peningkatan durasi diare berhubungan dengan penurunan indeks TB/U. Peningkatan durasi diare, demam, dan ISPA juga berhubungan dengan parameter gizi lain, yaitu penurunan indeks BB/U. Hambatan pertumbuhan yang disebabkan oleh diare berhubungan dengan gangguan absorpsi nutrien selama dan setelah episode diare. Hambatan pertumbuhan yang disebabkan oleh ISPA berhubungan dengan peningkatan kebutuhan metabolik dan gangguan intake makanan selama periode penyakit. ${ }^{17}$

Secara statistik tidak terdapat hubungan yang signifikan antara rerata frekuensi penyakit infeksi (ISPA dan diare) dengan kejadian stunting. Hasil penelitian ini sesuai dengan penelitian yang dilakukan di wilayah kerja Puskesmas Gilingan, Surakarta yang menyatakan bahwa frekuensi penyakit infeksi (ISPA dan diare) tidak memiliki hubungan yang signifikan dengan kejadian stunting pada anak usia $12-48$ bulan. $^{18} \mathrm{Hal}$ ini disebabkan stunting tidak hanya dipengaruhi oleh frekuensi penyakit infeksi, tetapi juga dipengaruhi oleh durasi penyakit infeksi dan asupan nutrien selama episode penyakit infeksi tersebut. ${ }^{19}$ 
Berat badan lahir memiliki hubungan yang bermakna dengan kejadian stunting. Penelitian ini sejalan dengan penelitian yang dilakukan di wilayah kerja Puskesmas Sungai Karias, Kabupaten Hulu Sungai Utara, Provinsi Kalimantan Selatan yang menyimpulkan bahwa faktor Berat Badan Lahir Rendah (BBLR) merupakan faktor risiko yang paling dominan terhadap kejadian stunting pada anak baduta. ${ }^{20}$ Karakteristik bayi saat lahir (BBLR atau BBL normal) merupakan hal yang menentukan pertumbuhan anak. Anak dengan riwayat BBLR mengalami pertumbuhan linear yang lebih lambat dibandingkan Anak dengan riwayat BBL normal. ${ }^{21}$ Periode kehamilan hingga dua tahun pertama usia anak merupakan periode kritis. Gangguan pertumbuhan pada periode ini sulit diperbaiki dan anak sulit mencapai tumbuh kembang optimal. ${ }^{22}$

Status pemberian ASI eksklusif tidak terdapat hubungan yang signifikan dengan kejadian stunting. Penelitian yang dilakukan di Desa Menduran, Kecamatan Brati, Kabupaten Grobogan, Provinsi Jawa Tengah mendapatkan hasil yang sama dengan penelitian ini, dimana status pemberian ASI eksklusif bukan faktor risiko stunting pada anak usia 1-3 tahun. ${ }^{23}$ Hal ini disebabkan oleh keadaan stunting tidak hanya ditentukan oleh faktor status pemberian ASI eksklusif, tetapi juga dipengaruhi oleh faktor lain seperti: kualitas Makanan Pendamping ASI (MP-ASI), kecukupan asupan gizi yang diberikan kepada anak setiap hari, serta status kesehatan bayi. $^{24}$

Tidak terdapat hubungan yang signifikan antara status imunisasi dasar dengan kejadian stunting. Penelitian yang dilakukan di wilayah kerja Puskesmas Siloam Tamako, Kabupaten Kepulauan Sangihe, Provinsi Sulawesi Utara juga mendapatkan hal demikian, yaitu tidak adanya hubungan yang signifikan antara status imunisasi dasar dengan kejadian stunting pada pada anak TK. $^{25}$ Anak yang tidak diberikan imunisasi dasar yang lengkap tidak serta-merta menderita penyakit infeksi. Imunitas anak dipengaruhi oleh faktor lain seperti status gizi dan keberadaan patogen. Ada istilah "herd immunity" atau "kekebalan komunitas" dalam imunisasi, yaitu individu yang tidak mendapatkan program imunisasi menjadi terlindungi karena sebagian besar individu lain dalam kelompok tersebut kebal terhadap penyakit setelah mendapat imunisasi. ${ }^{26}$ Sebagian responden yang memiliki anak dengan status imunisasi dasar tidak lengkap berada pada tingkat pendidikan dan pendapatan yang tinggi. Hal tersebut memungkinkan anak mendapatkan pola asuh yang baik dan kebutuhan nutrien yang terpenuhi sehingga status gizi anak menjadi baik.

\section{Hubungan Karakteristik Gizi dengan Kejadian Stunting}

Hubungan antara tingkat asupan energi dengan kejadian stunting secara statistik bermakna. Hasil yang sama diperoleh pada penelitian yang dilakukan di Kelurahan Kejawan Putih Tambak, Kecamatan Mulyorejo, Kota Surabaya, yaitu terdapat perbedaan tingkat kecukupan asupan energi yang signifikan antara balita stunting dan non stunting. ${ }^{27}$ Masa awal anakanak ditandai dengan pertumbuhan yang cepat (growth spurt). Mencukupi kebutuhan asupan energi yang adekuat merupakan hal yang sangat penting bagi anak. Energi tersebut bersumber dari makronutrien seperti: karbohidrat, lemak, dan protein. Karbohidrat merupakan sumber energi yang secara kuantitas paling penting bagi tubuh. Karbohidrat menyediakan energi untuk seluruh jaringan di dalam tubuh, terutama di otak yang normalnya menggunakan glukosa sebagai sumber energi aktivitas sel. Protein merupakan zat yang esensial bagi sel-sel tubuh. Lemak yang dikonsumsi dalam makanan dijadikan sebagai sumber energi dan asam lemak esensial. Asam lemak struktural merupakan bagian penting dari membran sel, serabut saraf, dan struktur sel secara umum. Cadangan lemak terutama pada jaringan adiposa sebagai sumber energi jangka panjang bagi tubuh. ${ }^{28}$

Hubungan antara tingkat asupan protein dengan kejadian stunting secara statistik tidak menunjukkan signifikansi. Hasil penelitian yang sama diperoleh pada penelitian yang dilakukan di Kelurahan Bandar Buat, Kecamatan Lubuk Kilangan, Kota Padang, yaitu tidak terdapat hubungan yang signifikan antara tingkat asupan protein dengan kejadian stunting pada siswa kelas I sekolah dasar. ${ }^{29} \mathrm{Hal}$ ini dengan teori dapat disebabkan asupan protein yang dikonsumsi dijadikan sebagai sumber energi. Protein merupakan satu dari tiga sumber energi utama bagi tubuh. Pemecahan protein akan terjadi apabila asupan energi tidak adekuat. Tubuh akan mengalami defisiensi protein 
apabila diet tidak mengandung protein dan/ atau energi dalam jumlah yang dibutuhkan. ${ }^{30}$ Ketidaksesuain ini juga dapat disebabkan oleh metode pengukuran tingkat asupan nutrien dengan menggunakan FFQ semi kuantitatif. Menurut Sulastri, pengukuran tingkat asupan nutrien dengan menggunakan FFQ semi kuantitatif belum menggambarkan jumlah asupan nutrien yang sesungguhnya. Hal ini disebabkan karena metode ini dipengaruhi oleh faktor lain, seperti: daya ingat responden, waktu, serta suasana saat wawancara. ${ }^{29}$

\section{SIMPULAN}

Terdapat hubungan yang bermakna antara tingkat asupan energi, rerata durasi sakit, berat badan lahir, tingkat pendidikan ibu, dan tingkat pendapatan keluarga dengan kejadian stunting pada anak usia 2459 bulan di wilayah kerja Puskesmas Andalas Kecamatan Padang Timur Kota Padang. Faktor tingkat pendidikan ibu memiliki hubungan paling dominan.

Tingkat asupan protein, rerata frekuensi sakit, status pemberian ASI eksklusif, status kelengkapan imunisasi dasar, tingkat pengetahuan ibu tentang gizi, dan jumlah anggota rumah tangga tidak menunjukkan hubungan yang signifikan dengan kejadian stunting.

\section{DAFTAR PUSTAKA}

1. Tim Nasional Percepatan Penanggulangan Kemiskinan (TNPPK). 100 kabupaten/ kota prioritas untuk intervensi anak kerdil (stunting). Jakarta: TNPPK; 2017.

2. Badan Penelitian dan Pengembangan Kesehatan Kementerian Kesehatan RI. Riset kesehatan dasar (Riskesdas). Jakarta: Balitbang Kemenkes RI; 2013.

3. Kementerian Kesehatan RI. Peraturan menteri kesehatan republik indonesia nomor 39 tahun 2016 tentang pedoman penyelenggaran program Indonesia sehat. Jakarta: Kemenkes RI; 2016.

4. Trihono, Atmarita, Tjandrarini $\mathrm{DH}$, Irawati A, Utami $\mathrm{NH}$, Tejayanti $\mathrm{T}$, et al. Pendek (stunting) di Indonesia, masalah dan solusinya. Jakarta: Lembaga Penerbit Balitbangkes; 2015.

5. Kementerian Perencanaan Pembangunan Nasional/ Badan Perencanaan Pembangunan Nasional. Rencana aksi nasional pangan dan gizi 2006-2010. Jakarta; 2007.
6. Dinas Kesehatan Kota Padang. Profil Kesehatan Kota Padang. Padang: Dinkes Kota Padang; 2017.

7. Rahayu A, Khairiyati L. Risiko pendidikan ibu terhadap kejadian stunting pada anak 6-23 bulan. Panel Gizi Makan; 2014;37(2):129-36.

8. Huang $W$. Understanding the effects of education on health: evidence from China. 2015 (diunduh Mei 2018). Tersedia dari: https://scholar.harvard.edu/ weihuang/publications/understanding-effectseducation-health-evidence-china

9. Ekawaty $\mathrm{M}$, Kawengian SES, Kapantow $\mathrm{NH}$. Hubungan antara pengetahuan ibu tentang gizi dengan status gizi anak umur 1-3 tahun di Desa Mopusi Kecamatan Lolayan Kabupaten Bolaang Mongondow Induk Sulawesi Utara. Manado. Jurnal e-Biomedik (eBM). 2015;3(2):609-14.

10. Aries $M$, Hardinsyah, Tuhiman $H$. Determinan gizi kurang dan stunting pada anak umur 0-36 bulan berdasarkan data program keluarga harapan $(\mathrm{PKH})$ 2007. Bogor: Jurnal Gizi dan Pangan. 2012;7(1):1926.

11. Rahmad AHAL, Miko A. Kajian stunting pada anak balita berdasarkan pola asuh dan pendapatan keluarga di Kota Banda Aceh. Banda Aceh. Jurnal Kesmas Indonesia. 2016;8(2):63-79.

12. Soetjiningsih. Tumbuh kembang anak. Jakarta: EGC; 1995.

13. Pipes LP. Nutrition in infancy and childhood. Missouri: Times Mirror/ Mosby College Publishing; 1985.

14. Kusumawati E, Rahardjo S, Sari HP. Model pengendalian faktor risiko stunting pada anak usia di bawah tiga tahun. Depok: Jurnal Kesehatan Masyarakat Nasional;2015;9(3):249-56.

15. Aridiyah FO, Rohmawati N, Ririanty M. Faktor-faktor yang mempengaruhi kejadian stunting pada anak balita di wilayah pedesaan dan perkotaan. e-Jurnal Pustaka Kesehatan. 2015;3(1):163-70.

16. Ponamon NS. Hubungan antara durasi dan frekuensi sakit balita dengan terjadinya stunting pada anak SD di Desa Kopandakan 1 Kecamatan Kotamobagu Selatan (skripsi). Manado: Fakultas Kesehatan Masyarakat Universitas Samratulangi; 2015.

17. Weisz A, Meuli G, Thakwalakwa C, Trehan I, Maleta $\mathrm{K}$, Manary M. The Duration of Diarrhea and Fever is 
Associated with Growth Faltering in Rural Malawian Children Aged 6-18 Months. Nutrition Journal. 2011;10(25):1-4.

18. Efendhi A. Hubungan kejadian stunting dengan frekuensi penyakit ISPA dan diare pada balita usia 12-48 bulan di wilayah kerja Puskesmas Gilingan Surakarta (skripsi). Surakarta: Universitas Muhammadiyah Surakarta; 2015.

19. Welasasih BD, Wirjatmadi RB. Beberapa faktor yang berhubungan dengan status gizi balita stunting. Surabaya: The Indonesian Journal of Public Health. 2012;8(3):99-104.

20. Rahayu A, Yulidasari F, Putri AO, Rahman F. Riwayat berat badan lahir dengan kejadian stunting pada anak usia bawah dua tahun. Jurnal Kesehatan Masyarakat Nasional. 2015;10(2):67-73.

21. Kusharisupeni. Growth faltering pada bayi di Kabupaten Indramayu Jawa Barat. Makara Kesehatan. 2002;6(1):25-8.

22. Rosmalina Y, Luciasari E, Aditianti, Ernawati F. Upaya pencegahan dan penanggulangan batita stunting: systematic review. Jurnal Gizi Indonesia. 2018;41(1):1-14.

23. Vaozia S, Nuryanto. Faktor risiko kejadian stunting pada anak usia 1-3 tahun (studi di Desa Menduran Kecamatan Brati Kabupaten Grobogan). Journal of Nutrition College. 2016;5(4):314-20.
24. Hindrawati N, Rusdiarti. Gambaran riwayat pemberian ASI eksklusif dengan kejadian stunting pada anak usia 6-24 bulan di Desa Arjasa Kecamatan Arjasa Kabupaten Jember. JKAKJ. 2018;2(1):1-7.

25. Bentian I, Mayulu N, Rattu AJM. Faktor risiko terjadinya stunting pada anak TK di wilayah kerja Puskesmas Siloam Tamako Kabupaten Kepulauan Sangihe Provinsi Sulawesi Utara. Jurnal IImu Kesehatan Masyarakat Unsrat. 2015;5(1):1-7.

26. Kementerian Kesehatan RI. Mengenal herd immunity dalam imunisasi. 2018 (diunduh Mei 2018). Tersedia dari: http://www.depkes.go.id/ pdf.php?id=17042600003

27. Damayanti RA, Muniroh L, Farapti. Perbedaan tingkat kecukupan zat gizi dan riwayat pemberian ASI eksklusif pada balita stunting dan non stunting. Media Gizi Indonesia. 2016;11(1):61-9.

28. Barilla Center for Food and Nutrition. Healthy growth and nutrition in children. Parma: Barilla Center for Food and Nutrition; 2009.hlm.8-9.

29. Sulastri D. Faktor determinan kejadian stunting pada anak usia sekolah di Kecamatan Lubuk Kilangan Kota Padang. Padang: Majalah Kedokteran Andalas. 2012;1(36):39-50.

30. Webster-Gandy J, Madden A, Holdsworth M, editor (penyunting). Gizi dan dietetika. Jakarta: EGC; 1995. 